\title{
The Effect of Company Characteristics on the Extent of Sustainability Report Disclosures
}

\author{
Bahtiar Effendi \\ \{bahtiar.effendi90@gmail.com\} \\ Universitas Matana, J1. CBD Barat Kav. 1, Tangerang 15810, Banten, Indonesia
}

\begin{abstract}
This study aims to examine the characteristics of the company consisting of leverage, profitability, company size, and company age to the extent of disclosure of sustainability report. There are 48 companies engaged in manufacturing of chemical and animal feed sub-sectors in 2012-2017 as samples. These samples were selected using the purposive sampling method. Then the data are analyzed using multiple regression methods. The results of the study show that company characteristics that are proxied by leverage, profitability, company size, and company age do not affect the extent of disclosure of sustainability report.
\end{abstract}

Keywords: sustainability report, company characteristics, accounting.

\section{Introduction}

This research is based on several facts regarding the low awareness of companies in Indonesia in carrying out corporate social responsibility stated in the sustainability report, especially manufacturing companies in the chemical and animal feed sub-sector that have the largest waste production compared to other companies. Waste produced by manufacturing companies in the chemical sub-sector and animal feed has a relatively large negative impact that is detrimental to the environment and surrounding communities where the company carries out its production activities. The corporate social responsibility expressed in the sustainability report is a continuing commitment by each company to act ethically by contributing to the economic development of the environment and surrounding communities that are negatively affected by the production of waste produced by each company. These contributions can be carried out in various ways as a form of compensation by the company which has caused harm to the environment and surrounding communities, one of which is by increasing the standard of living of the employees of the company and their families and the environment and the communities where the company operates.

There are several references from countries that have implemented Corporate Social Responsibility for companies in other countries as a reference in carrying out good social responsibility. Some of these countries are Germany, Canada, Australia, France, the United Kingdom, the United States, the Netherlands, they adopted the Corporate Social Responsibility code of conduct covering environmental aspects, industrial relations, gender, corruption, and human rights. So based on these aspects, they developed a regulation to regulate Corporate Social Responsibility. One example can be seen in Australia which allows companies to make annual reports on corporate social responsibility (sustainability reporting) and regulate the standardization of aspects such as the environment, industrial relations and 
human rights. Meanwhile, another example can be seen in the country of Canada setting the sustainability reporting report on aspects of industrial relations, environmental protection, problem solving, and health.

Wibisono explained that Corporate Social Responsibility is a continuing commitment by each company to act ethically by contributing economic development to the environment and surrounding communities that are negatively affected by the production of waste produced by each company. These contributions can be carried out in various ways as a form of compensation by companies that have caused harm to the environment and surrounding communities, one of which is by increasing living standards for the employees of the company itself and their families and the environment and surrounding communities where the company operates [1] .

Actions on social responsibility carried out by each company can be measured and seen on indicators issued by the Global Reporting Initiative (GRI), an international independent standards organization that helps business companies, governments and other organizations understand and communicate actions social responsibility carried out by each company on issues such as climate change, human rights and corruption. The latest reporting framework issued by the Global Reporting Initiative (GRI) organization is a standard launched in October 2016 entitled "G4 Sustainability Reporting Guidelines" developed by the Global Sustainability Standards Agency (GSSB).

According to Kasmir, leverage is a ratio that is used to measure the level of debt usage both short-term and long-term debt in financing company assets [2]. In this study, the method for obtaining leverage values uses Total Debt to Total Assets Ratio, which is a comparison between the amount of current debt and long-term debt with the total known assets of the company. This ratio shows how much part of the total assets are spent using debt as indicated by a percentage. Sawir explained that this leverage ratio shows the proportion between liabilities and all assets owned by the company [3]. Following is the formula to get the leverage value is equal to total debt divided by Total Assets.

Profitability according to Syafri is a ratio that can show the company's ability to earn profits through existing sources such as cash, sales operations, capital, number of employees, number of branches, and others [4]. In this study, the method for obtaining value from profitability is the net profit margin. Bastian, et al. (2006) explained that the value of net profit margin can be obtained by comparing net income with net sales. This ratio can help managers in making strategic policies in selling prices that can be applied by the company and shows the manager's ability to control the company's operating expenses [5]. The value of the net profit margin can be categorized as good if the value is greater than $5 \%$, meaning that the company can be considered successful in generating profits if it can produce a profitability value above $5 \%$ and vice versa. Net Profit Margin is calculated by the formula of Net Profit divided by Sales multiplied by $100 \%$.

The size of the company is a value that can indicate the level of large or small company, the higher the value of the company measured by the value of capital used to finance the assets of the company will increase the attention of the market and the public in general. Putra et al. (2011) provide the formula for getting the value of company size is equal to total assets [6]. The age of the company based on Harry is a company that has an unlimited age and can demonstrate the company's ability to maintain its business continuity. The age of the company is equal to the year of research reduced by the year of standing [7].

This research was conducted to answer the formulation of the problem found, namely :

1. Does leverage on manufacturing companies in the chemical sub-sector and animal feed affect the extent of disclosure of sustainability reports? 
2. Does profitability in a chemical and animal feed sub-sector manufacturing company affect the extent of disclosure of sustainability report?

3. Does the size of the company in a chemical and animal feed sub-sector manufacturing company influence the extent of disclosure of sustainability report?

4. Does the age of the company in a chemical and animal feed sub-sector manufacturing company influence the extent of disclosure of sustainability report?

The previous research journals which were the basis of the variable takers that the researchers found were as follows Jayanti, et al. [8], Kamaliah, et al. [9], Darmawan [10], Permatasari [11], Rhomdona [12], Pebrinana, et al. [13], Arjanggie and Aulia [14], Purba [15], Wahyuni [16], Rofiqkoh [17], Wardani [18], Andrayani [19], Aprilliani [20]. Based on previous studies, the researcher draws the hypothesis as follows:

$\mathrm{H}_{1}$. Leverage does not affect the extent of sustainability report disclosure.

$\mathrm{H}_{2}$. Profitability influences the extent of disclosure of sustainability report.

$\mathrm{H}_{3}$. The size of the company influences the extent of disclosure of sustainability report.

$\mathrm{H}_{4}$. The age of the company influences the extent of disclosure of sustainability report.

\section{Research Method}

The study took annual reports on eight manufacturing companies taken from web.idx.co.id and data collection per year for 2012 to 2017. The chemical manufacturing companies are Barito Pacific Tbk (BRPT), Budi Acid Jaya Tbk (BUDI), Chandra Asri Petrochemical (TPIA), Duta Pratiwi Nusantara Tbk (DPNS). The animal feed manufacturing companies are Charoen Pokphand Indonesia Tbk (CPIN), Japfa Comfeed Indonesia Tbk (JPFA), Malindo Feedmill Tbk (MAIN), and Siearad Produce Tbk (SIPD)

So, the sample used for this study amounted to 48 samples with details of 8 manufacturing companies for 6 years of data. The financial statements contained in the annual report are used to obtain the value of the independent variable, namely company characteristics specified as leverage, profitability, company size, and company age, and other reports from annual reports are used to obtain the value of the sustainability report disclosure in 87 Global Reporting Initiative indicator 4.

\section{Result and Discussion}

After all samples are processed using the analytical method mentioned above, the following results are obtained as the following. Based on Table 1., it can be seen that the correlation between the independent variables listed in the Pearson correlation has a dominant value above 0.05 or $5 \%$. So the conclusion is that the research data have passed the normality test.

Table 1. Normality Test

\begin{tabular}{llrrrrr}
\hline & & \multicolumn{1}{c}{ SRI } & \multicolumn{1}{c}{ LVRG } & \multicolumn{1}{c}{ PRFT } & \multicolumn{1}{c}{ SIZE } & \multicolumn{1}{c}{ AGE } \\
\hline Pearson Correlation & SRI & 1.000 & .024 & .035 & .097 & .226 \\
& LVRG & .024 & 1.000 & -.542 & .484 & .001 \\
& PRFT & .035 & -.542 & 1.000 & -.249 & .097
\end{tabular}




\begin{tabular}{rlrrrrr} 
& SIZE & .097 & .484 & -.249 & 1.000 & .485 \\
Sig. (1-tailed) & AGE & .226 & .001 & .097 & .485 & 1.000 \\
& SRI &. & .437 & .407 & .256 & .061 \\
& LVRG & .437 &. & .000 & .000 & .499 \\
& PRFT & .407 & .000 & & .044 & .256 \\
& SIZE & .256 & .000 & .044 &. & .000 \\
$\mathrm{~N}$ & AGE & .061 & .499 & .256 & .000 &. \\
& SRI & 48 & 48 & 48 & 48 & 48 \\
& LVRG & 48 & 48 & 48 & 48 & 48 \\
& PRFT & 48 & 48 & 48 & 48 & 48 \\
& SIZE & 48 & 48 & 48 & 48 & 48 \\
& AGE & 48 & 48 & 48 & 48 & 48 \\
\hline
\end{tabular}

Furthermore, we can also see the normality test based on the results of the running data shown in Figure 1. It explains that the research data has been normally distributed as evidenced by the p-plot dominant approaching the fit line. So the conclusion is that the spread of independent variables has normally distributed.

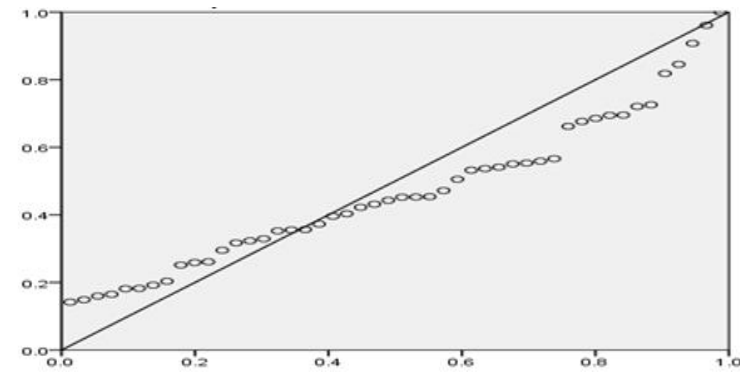

Fig. 1. Normality Test

After the data sample examination has normal distribution, then we continue with multicollinearity testing. Based on the multicollinearity test results shown in Table 2., we can that the tolerance value $>0.01$ and the VIF value $<10$. So the conclusion is that the data can be said to be reliable or reliable.

Table 2. Multicolinierity Test

\begin{tabular}{llrr}
\hline Model & & Tolerance & \multicolumn{1}{l}{ VIF } \\
\hline 1 & (Constant) & & \\
& LVRG & .551 & 1.815 \\
& PRFT & .695 & 1.439 \\
& SIZE & .529 & 1.889 \\
& AGE & .682 & 1.467 \\
\hline
\end{tabular}


Based on Table 3. below, it can be seen that all four independent variables have sig values. $>0.05$. This shows that there are no symptoms of heteroskedasitisas in the four independent variables.

Table 3. Heteroscedastisity Test

\begin{tabular}{|c|c|c|c|c|c|c|}
\hline \multicolumn{2}{|c|}{ Model } & \multirow{2}{*}{$\begin{array}{l}\text { Unstandardized } \\
\text { Coefficients } \\
\text { B } \\
\end{array}$} & & \multirow{2}{*}{$\begin{array}{c}\text { Standardized } \\
\text { Coefficients } \\
\text { Beta } \\
\end{array}$} & \multirow[t]{2}{*}{$\mathrm{T}$} & \multirow[t]{2}{*}{ Sig. } \\
\hline & & & Std. Error & & & \\
\hline \multirow[t]{5}{*}{1} & (Constant) & -.008 & .025 & & -.339 & .736 \\
\hline & LVRG & .009 & 030 & .063 & .315 & .754 \\
\hline & PRFT & .009 & .049 & .035 & .194 & .847 \\
\hline & SIZE & -.001 & .004 & -.043 & -.211 & .834 \\
\hline & AGE & .080 & .059 & .244 & 1.356 & .182 \\
\hline
\end{tabular}

To support the results of this test, we need to do heteroscedasticity testing. This test uses a scatterplot as shown in Figure 2. below.

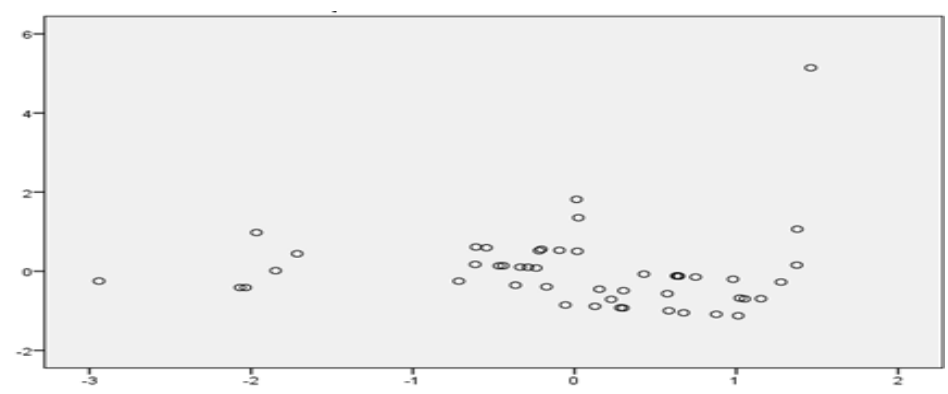

Fig. 2. Heteroscedastisity Test

Based on Table 4. below, we can see that Durbin-Watson has a value of 1,988 which is in the period between -2 to 2 . This interpretion is that the value does not occur autocorrelation.

Table 4. Autocorelation Test

\begin{tabular}{lr}
\hline Model & Durbin- Watson \\
\hline 1 & 1.988 \\
\hline
\end{tabular}

$\mathrm{T}$ test or partial hypothesis using the coefficient of data results from multiple linear regression in the IBM SPSS Statistics application version 24. The results of running data are as in Table 5. below: 
Table 5. Uji T / Partial Hypothesis

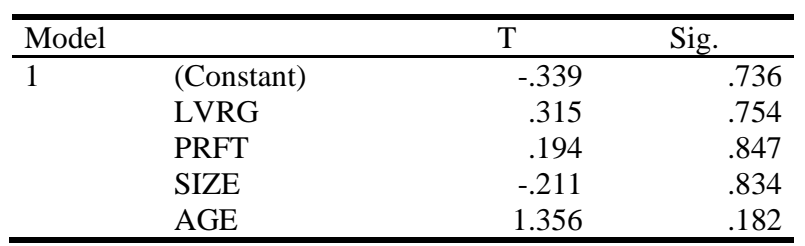

Testing the partial hypothesis in Table 5. states the effect of the independent variables tested, namely leverage, profitability, firm size, and firm age on the extent of disclosure of sustainability report. The partial hypothesis testing on the leverage free variable has a t-count value of 0.315 which is smaller than the t-table of 2.017 and a significant value of 0.754 is greater than 0.05 . So, it can be concluded that the leverage value in 48 data tested samples does not affect the extent of disclosure of sustainability report. These results support the results of research in previous studies conducted by Darmawan, Rhomdona, Pebrinana et al., and Wahyuni.

Testing the partial hypothesis on the independent variable profitability has a t-count value of 0.194 smaller than the t-table value of 2.017 and a significant value of 0.847 greater than 0.05 . So, it can be concluded that the profitability value of 48 data tested samples did not significantly influence the extent of sustainability report disclosure. These results support the results of previous studies conducted by Kamaliah et al., Rhomdona, Pebrinana et al., Wahyuni, and Rofiqkoh.

Testing the partial hypothesis on the independent variable size of the company has a tcount value of -0.211 smaller than the t-table value of 2.017 and a significant value of 0.836 greater than 0.05 . So, it can be concluded that the value of the company size from the 48 data tested samples did not significantly influence the extent of disclosure of sustainability report. These results support the results of previous studies conducted by Darmawan, Wardani, Andrayani, Aprilliani.

Testing the partial hypothesis on the independent variables of the age of the company has a $\mathrm{t}$-count value of 1.356 smaller than the t-table value of 2.017 and a significant value of 0.182 greater than 0.05 . So, it can be concluded that the value of the company size from the 48 data tested samples did not significantly influence the extent of disclosure of sustainability report. These results support the results of previous studies conducted by Pebrinana, et al., Arjanggie and Aulia, and Aprilliani.

\section{Conclusion}

The result has shown that the leverage does not affect the extent of sustainability report disclosure, which means that the level of value of the use of funds or debt to the financing of assets owned by the company does not affect the extent of disclosure of sustainability report. Then, the profitability does not affect the extent of sustainability report disclosure, which means that the higher the level of profit obtained by manufacturing companies in the chemical sub-sector and animal feed is not a determining factor in the increasing social responsibility disclosed in the sustainability report carried out by the company. 
Moreover, the size of the company does not affect the extent of sustainability report disclosure, which means that the higher the value of assets held by manufacturing companies in the chemical sub-sector and animal feed is not a determinant of the higher and wider social responsibility expressed in the company's sustainability report. On the other hand, the age of the company does not affect the extent of sustainability report disclosure, which means that the longer the age of manufacturing companies in the chemical sub-sector and animal feed does not make the higher and wider the value of sustainability report disclosure carried out by the company.

\section{References}

[1]Wibisono, Y.: Membedah Konsep dan Aplikasi Corporate Social Responsibility. Gresik : Fascho Publishing (2007)

[2]Kasmir: Analisis Laporan Keuangan. Jakarta: Rajawali Pers (2013)

[3]Sawir, A.: Analisis Kinerja Keuangan dan Perencanaan Keuangan. Jakarta : PT. Gramedia Pustaka Utama (2008)

[4]Syafri, H.S.: Analisis Kritis Atas Laporan Keuangan. Jakarta : Raja Grafindo Persada (2008)

[5]Bastian, et al:: Akuntansi Perbankan Edisi 1. Jakarta: Salemba Empat (2006)

[6]Putra, et al.: Pengaruh Size, Profitabilitas, Leverage, Kepemilikan Dalam Negeri dan Kepemilikan Asing Terhadap Pengungkapan Tanggung Jawab Sosial Perusahaan (Survey Pada Perusahaan Industri Yang Terdaftar di Bursa Efek Indonesia). Jambi : Universitas Seri Humaniora (2011)

[7]Harry: Akuntansi Perusahaan Dagang dan Jasa. Bandung: Alfa Beta (2011)

[8]Jayanti, et al.: Analisis Pengaruh Size, Profitabilitas, dan Leverage Terhadap Pengungakapan CSR Pada Perusahaan yang Terdaftar di Bursa Efek Indonesia. Semarang : Universitas Diponegoro (2013)

[9]Kamaliah, et al.: Pengaruh Karakteristik Perusahaan Terhadap Pengungkapan Tanggung Jawab Sosial Pada Perusahaan Perbankan dan Lembaga Keuangan Non Perbankan yang Terdaftar di BEI. Pekanbaru: Universitas Riau (2013)

[10]Darmawan, M.: Pengaruh Profitabilitas dan Leverage Terhadap Pengungkapan Corporate Social Responsibility Perusahaan Manufaktur yang Terdaftar di Bursa Efek Indonesia (BEI). Surabaya : Sekolah Tinggi Ekonomi Perbanas (2014)

[11]Permatasari, H.D.: Pengaruh Leverage, Tipe Industri, Ukuran Perusahaan, dan Profitabilitas Terhadap Corporate Social Responsibility (CSR). Semarang : Universitas Diponegoro (2014)

[12]Rhomdona, M.R.: Pengaruh Profitabilitas dan Leverage Terhadap Tingkat Pengungkapan Tanggung Jawab Sosial Perusahaan Serta Perbandingan Masing-Masing Variabel Sebelum dan Sesudah IFRS (2014)

[13]Pebrinana, et al.: Pengaruh Profitabilitas, Leverage, Umur Perusahaan, Komposisi Dewan Direksi, dan Kepemilikan Insititusional Pada Pengungkapan Corporate Social Responsibility (CSR) di Bursa Efek Indonesia. Bali : Universitas Udayana (2014)

[14]Arjanggie dan Aulia, R.: Pengaruh Profitabilitas dan Umur Perusahaan Terhadap Pengungkapan Tanggung Jawab Sosial Perusahaan (Studi Empiris Pada Perusahaan Industri Dasar dan Kimia yang Terdaftar di Bursa Efek Indonesia). Semarang : Universitas Diponegoro (2015)

[15]Purba, I.: Pengaruh Ukuran Perusahaan dan Leverage Terhadap Profitabilitas dan Pengungkapan Corporate Social Responsibility. Bali : Universitas Udayana (2015)

[16]Wahyuni, S.: Pengaruh Profitabilitas, Umur Perusahaan, Ukuran Perusahaan, dan Leverage Terhadap Pengungkapan Corporate Social Responsibility Studi Empiris Pada Sektor Pertambangan yang Terdaftar di BEI. Depok: Universitas Gunadarma (2015)

[17]Rofiqkoh, E.: Pengaruh Profitabilitas, Leverage, dan Ukuran Perusahaan Terhadap Pengungkapan Tanggung Jawab Sosial Perusahaan. Surabaya : Sekolah Tinggi Ilmu Ekonomi Indonesia (STIESIA) (2016) 
[18]Wardani, A.W.: Pengaruh Karakteristik Perusahaan Terhadap Pengungkapan Corporate Social Responsibility (CSR) (Studi Empiris pada Perusahaan Manufaktur yang Terdaftar di Bursa Efek Indonesia Tahun 2011-2013). Surakarta: Universitas Muhammadiyah (2016)

[19]Andrayani, D.: Pengaruh Profitabilitas, Umur Perusahaan, dan Ukuran Perusahaan Terhadap Corporate Social Responsibility (CSR) Disclosure. Surabaya : Sekolah Tinggi Ilmu Ekonomi Perbanas (2016)

[20]Aprilliani, D.A.: Pengaruh Umur Perusahaan, Ukuran Perusahaan, Leverage, Dewan Komisaris, dan Kepemilikan Saham Publik Terhadap Corporate Social Responsibility (CSR).Surakarta : Universitas Muhammadiyah (2017) 